\title{
Ameliorative Potentials of Boerhavia diffusa Ethanolic Leaf Extract on cypermethrin-Induced Reproductive Dysfunction in Wistar Rats
}

\section{Omoirri $\mathrm{MA}^{1 *}$, Ehebha $\mathrm{SE}^{2}$, Madubogwu $\mathrm{NU}^{3}$, Gbagbeke $\mathrm{KO}^{4}$ and Uyovwiesevwa $\mathrm{AJ}^{4}$}

${ }^{1}$ Department of Pharmacology and Toxicology, Faculty of Pharmaceutical Sciences, Nnamdi Azikiwe University, Nigeria

${ }^{2}$ Department of Human Anatomy and Cell Biology, Edo University, Nigeria

${ }^{3}$ Department of Pharmacology and Toxicology, Chukwuemeka Odumegu University, Nigeria

${ }^{4}$ Department of Human Physiology, Faculty of Basic Medical Sciences, College of Health Sciences, Delta State University, Nigeria

\section{Research Article \\ Volume 5 Issue 1}

Received Date: December 17, 2020

Published Date: January 26, 2021

DOI: $10.23880 /$ jhua-16000151

*Corresponding author: Omoirri MA, Department of Pharmacology and Toxicology, Faculty of Pharmaceutical Sciences, Nnamdi Azikiwe University, Akwa, Anambra State, Nigeria, Email: osgiedeprof@yahoo.com

\section{Abstract}

With rising global reports on reproductive and hematological health indicators, numerous animal based researches have more often focused on herbal-based medical remedies. In this study, the ameliorative potentials of ethanolic leaf extract of Boerhavia diffusa was investigated on reproductive and selected hematological variables in wistar rats [packed cell volume (PCV), total white blood cell count (TWBCC), total red blood cell (TRBCC) count and total Platelet count (TPC)]. Twenty five (25) female wistar rats (between 150-200 g) were procured and acclimatized for two weeks in the animal house of Ambrose Alli University, Ekpoma, Edo State. The rats were then grouped into five (5) groups of five rats each $(n=5)$. While group I animals received standard rat chow and water at liberty (control), reproductive dysfunction was orally induced in group II rats, using $3.83 \mathrm{mg} / \mathrm{kg}$ bw of cypermethrin for 14 days. Groups III, IV and V received (orally) $200 \mathrm{mg} / \mathrm{kg} \mathrm{bw,} 300 \mathrm{mg} / \mathrm{kg}$ bw and $400 \mathrm{mg} / \mathrm{kg}$ bw of Boerhavia diffusa extract (ethanolic) for five weeks respectively; haven also induced reproductive dysfunction. At the end of the period of administration, animals were euthanized under chloroform anaesthesia and blood sample obtained for hematological analysis, while also harvesting and observing the ovaries for histo-architectural changes. Results from one way analysis of variance (ANOVA) showed a statistically significant $(p<0.05)$ dose-dependent increase in the PCV TPC and TRBCC levels of all groups compared to control, while TWBCC increased insignificantly across groups. More studies to corroborative the observations from this works highly recommended.

Keywords: Hematology; Reproduction; Boerhavia diffusa

\section{Introduction}

Boerhaavia diffusa (Family- Nyctaginaceae), is a very controversial plant that has drawn numerous attention across the globe as a result of its immune-modulatory effects
[1], anti-lymph and anti-proliferative activity, anti-viral effects [2], as well as its anti-biotic actions. The plant has also been reported to be useful in combating anaemia $[3,4]$, as a purifier of blood [5], speedy healing of wounds [6], in antiinflammation [7], etc. Its implications in the quick stoppage 
of bleeding has also been reported [8], not neglecting its diuretic, cardiotonic [9], antioxidant [10], antihemorrhagic [11], antispasmodic [12], antimicrobial [13], cytotoxic and anticancer roles. Boerhaavia diffusa is widely dispersed, occurring throughout India, the Pacific, and southern United States. Its flowers are small, around $5 \mathrm{~mm}$ in diameter, with round pollens of roughly 65 microns in diameter. This wide range is explained by its small fruit, which are very sticky and grow a few inches off the ground, ideally placed to latch on to small migratory birds as they walk by Hilou A [13]. Although a true and accurate accounting of the native range of Boerhavia diffusa has not been determined. However, it is very widespread, and has become naturalized in many places.

The root of Boerhavia diffusa acts as an anticonvulsant, analgesic [14], laxative medication that when rubbed in honey can be locally applied for cataract, chronic conjunctivitis and blepharitis. Useful for curing heart diseases, anemia and edema (or oedema), Punarnava is an effective remedy that reduces swelling and foul smell in skin disorders. Apart from the root, Punarnava's leaves are also consumed as a vegetarian dish to reduce oedema. As an Ayurvedic medicine, this herb is said to cure disorders like intestinal colic, kidney disorders, cough, hemorrhoids, skin diseases, alcoholism, insomnia, eye diseases, asthma and jaundice, Boerhavia diffusa (Sri Lankan Name Pita Sudu sarana best green medicene for Diabetes [15].

Recently, a growing number of studies have revealed that reproductive disorders in animals may have a negative impact on pregnancy, from implantation until term. In addition, humans with reproductive disorders often require assisted reproductive technologies to affect pregnancy outcomes. Thus, it is a difficult task to distinguish the contribution of specific reproductive disorders relative to the interventions required for pregnancy success $[15,16]$. Also, Hormones and inflammatory mechanisms are implicated in the major events of reproductive functions, while increasing evidence shows that hormonal aberrations and a hyper-inflammatory states may lead to derangements in cross talks that predisposes one to reproductive dysfunction.

Similarly, hematology, which studies the numbers and morphology of the cellular elements of the blood - the red cells (erythrocytes), white cells (leucocytes), and the platelets (thrombocytes) and the use of these results in the diagnosis and monitoring of disease $[15,16]$ is useful in the diagnosis of many diseases as well as investigation of the extent of damage to blood [17]. Hematological parameters are good indicators of the physiological status of animals. Hematological parameters are those parameters that are related to the blood and blood forming organs.

\section{Aim of Study}

This study investigated the histological and hematological changes in Boerhavia diffusa extract treated, reproductive dysfunctional wistar rats. Specifically, the study;

- Determined the effects of ethanolic extract of Boerhavia diffusa leaf on body weights.

- Examined the changes in selected hematological variables [packed cell volume (PCV), total white blood cell count (TWBCC), total red blood cell (TRBCC) count and total Platelet count (TPC)], following administration of ethanolic leaf extract of Boerhavia diffusa to wistar rats.

- Investigated the histo-architectural changes in the ovary of Boerhavia diffusa treated rats.

\section{Materials and Methods}

\section{Study Area}

This study was conducted within the animal unit of the faculty of basic medical sciences, college of medicine, Ambrose Alli University, Ekpoma, Edo State.

\section{Study Design}

Study was designed to be experimental in nature, procuring a total of Twenty five (25) wistar rats (between 150-200 g), and acclimatizing them for two weeks within the animal house of Ambrose Alli University, Ekpoma, Edo State. The rats were then grouped into five (5) groups of five rats each $(n=5)$. While group I animals received standard rat chow and water at liberty (normal control), reproductive dysfunction was orally induced in group II rats, using $3.83 \mathrm{mg} /$ $\mathrm{kg}$ bw of cypermethrin for 14 days (negative control). Groups III, IV and V received (orally) $200 \mathrm{mg} / \mathrm{kg} \mathrm{bw}, 300 \mathrm{mg} / \mathrm{kg}$ bw and $400 \mathrm{mg} / \mathrm{kg}$ bw of Boerhavia diffusa extract (ethanolic) for five weeks respectively; haven also induced reproductive dysfunction with $3.83 \mathrm{mg} / \mathrm{kg}$ bw of cypermethrin.

\section{Extract Preparation}

After obtaining Boerhavia diffusa leafs from local farms within the study area, they were then sun-dried for days and weighed continuously with electronic balance. Dry leafs were then homogenized in pestle and mortar and then filtered with Wattmann filter paper. Next, graded doses of Boerhavia diffusa [high, medium and low] were estimated from previously established lethal dose. About $2 \mathrm{~g}$, $3 \mathrm{~g}$ and $4 \mathrm{~g}$ were dissolved in $200 \mathrm{ml}, 300 \mathrm{ml}$ and $400 \mathrm{ml}$ of ethanol to make their respective stock solutions. The body weights of the animals were then taken and the dose of test drugs in millilitre to be administered was calculated using; 


$$
\% \text { yield }=\frac{=\quad \text { Weight of extract } X 100}{\text { Weight of plant sample used }}
$$

\section{Body Weight Determination}

Using the electronic weighing scale (Cardinal Scale Manufacturing Co., Webb City, MO), body weights of animals were obtained and recorded weekly (in grams (g)) throughout the period of administration (five weeks).

\section{Inducing Reproductive Dysfunction}

Reproductive Dysfunction was induced by the oral administration of cypermethrin $(3.83 \mathrm{mg} / \mathrm{kg} \mathrm{bw}$ ) for 14 days according to the procedure of $\mathrm{Hu}$ [18].

\section{Samples Collection}

Following period of administration, animals were euthanized by cervical decapitation, then, collection of blood sample from the superior vena cava followed, with the aid of a $5 \mathrm{ml}$ syringe. Collected samples were then centrifuged at $3000 \mathrm{rpm}$ for 15 minutes, while refrigerating collected sera for hematological analysis [packed cell volume (PCV), total white blood cell count (TWBCC), total red blood cell (TRBCC) count and total Platelet count (TPC)] at $-20^{\circ} \mathrm{C}$. Also, animals were dissected to remove the ovaries; which were then cleared of adherent tissues for histological studies.

\section{Ethical Clearance}

Ethical approval was sought from the Research and Ethics Committee of the College of Medicine, Ambrose Alli University, Ekpoma, Edo State, Nigeria.

\section{Statistical Analysis}

Obtained results were represented as mean standard deviation. Statistical analysis was done using the one-way analysis of variance (ANOVA) and post-hoc (tukey) test. Statistics was carried out with graph pad prism software (version 8.0). A p-level less than 0.05 were considered as statistically significant.

\section{Results}

\begin{tabular}{|c|c|c|c|c|c|c|}
\hline \multirow{2}{*}{$\begin{array}{c}\text { Treatments } \\
\text { Groups }\end{array}$} & \multicolumn{4}{|c|}{ Body Weights } & \multirow{2}{*}{ ANOVA } & \multirow{2}{*}{ Remark } \\
\cline { 2 - 7 }$n$ & IBW & $\mathbf{1 4}^{\text {th }}$ day & $\mathbf{2 8}^{\text {th }}$ Day & FBW & & \\
\hline Control (I) & $154.17 \pm 4.54$ & $152.52 \pm 4.07$ & $155.31 \pm 5.05$ & $157.20 \pm 7.50$ & 0.2001 & Insig. \\
\hline II & $142.02 \pm 6.76$ & $140.0 \pm 6.29$ & $144.80 \pm 6.17$ & $145.00 \pm 6.82$ & 0.0001 & Sig. \\
\hline III & $150.61 \pm 7.56$ & $152.50 \pm 7.10$ & $151.61 \pm 7.58$ & $153.60 \pm 7.51$ & 0.01 & Sig. \\
\hline IV & $167.01 \pm 8.92$ & $162.30 \pm 8.51$ & $161.60 \pm 7.76$ & $160.32 \pm 7.13$ & 0.0005 & Sig. \\
\hline V & $170.01 \pm 9.12$ & $169.11 \pm 8.11$ & $172.42 \pm 9.41$ & $175.22 \pm 9.97$ & 0.0001 & Sig. \\
\hline
\end{tabular}

Table I: Body Weight Changes in Boerhavia diffusa Extract Administration.

All values are represented as mean \pm SEM. From the table above, there was a reduction in body weight of negative control group (II) compared to group I. whereas, administration of varying doses of ethanolic Boerhavia diffusa leaf extract caused a significant $(\mathrm{p}<0.05)$ weekly recovery in body weights of all experimental animals compared with control.

\begin{tabular}{|c|c|c|c|c|}
\hline \multirow{2}{*}{$\begin{array}{c}\text { Treatment } \\
\text { Groups }\end{array}$} & \multicolumn{4}{|c|}{ Hematological Parameters } \\
\cline { 2 - 4 } & PCV (\%) & \multirow{2}{*}{ TRBCC $\left(\mathbf{*}^{*} \mathbf{1 0}^{\mathbf{3}} / \mathbf{m m}^{\mathbf{3}} \mathbf{)}\right.$} & $\mathbf{T W B C C}$ & TPC \\
\cline { 3 - 5 } & $37.04 \pm 1.23$ & $3.21 \pm 0.07$ & $3.62 \pm 0.32$ & $170.10 \pm 21.26$ \\
\hline Control & $32.42 \pm 1.10^{*-}$ & $2.64 \pm 0.01^{*-}$ & $3.53 \pm 0.12 \#^{-}$ & $164.24 \pm 18.64^{*-}$ \\
\hline II & $41.10 \pm 1.61^{*+}$ & $3.46 \pm 0.48^{*+}$ & $3.64 \pm 0.58 \#^{+}$ & $168.28 \pm 21.04^{*-}$ \\
\hline III & $43.09 \pm 1.82^{*+}$ & $3.72 \pm 0.66^{*+}$ & $3.70 \pm 0.71 \#^{+}$ & $174.13 \pm 26.27^{*+}$ \\
\hline IV & $46.62 \pm 1.94^{*+}$ & $4.37 \pm 0.95^{*+}$ & $3.81 \pm 0.86 \#^{+}$ & $175.38 \pm 29.08^{*+}$ \\
\hline V & &
\end{tabular}

PCV: packed cell volume, TWBCC: total white blood cell count, TRBCC: total red blood cell count, and TPC: total Platelet count. All values are represented as mean \pm SEM. Also, ${ }^{*+}=$ Significant increase $(p<0.05),{ }^{*=}$ Significant decrease, $\#^{+}=$Insignificant increase $(p$ $>0.05)$, and \#-= Insignificant decrease,

Table 2: Comparative Changes in Hematological Parameters in Boerhavia diffusa Extract Administration 
From above table, there was a noticeable significant reduction in all assayed hematological parameters for negative control group (II) but for TWBCC which was insignificant compared to control (group I). however, administration of varying doses of ethanolic Boerhavia diffusa leaf extract caused a significant improvement in all variables as compared to control; even though these increases were insignificant across groups for TWBCC as compared with control.

\begin{tabular}{|c|c|c|c|c|c|}
\hline Groups/Effects & Control & II & III & IV & V \\
\hline Number of primary follicles & + & ++ & + & + & ++ \\
\hline Number of secondary follicles & ++ & ++ & ++ & + & ++ \\
\hline Number of matured follicles & + & + & ++ & + & + \\
\hline Cystic follicles & - & + & - & - & - \\
\hline
\end{tabular}

Key: - not observed, + low, ++ moderate, +++ high.

Table 3: Histo-Pathological Observations in Ovary of Boerhavia diffusa Extract Treated Rats.

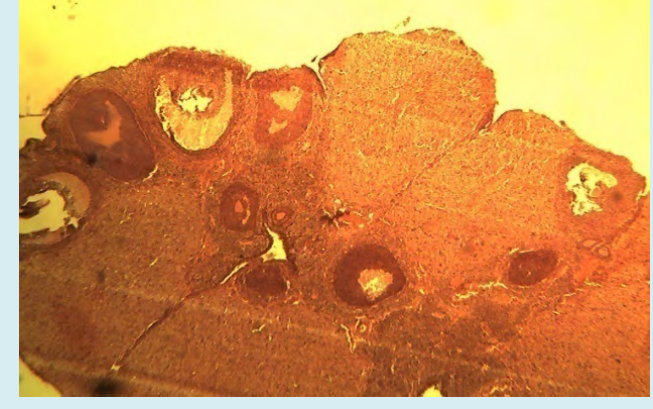

Control

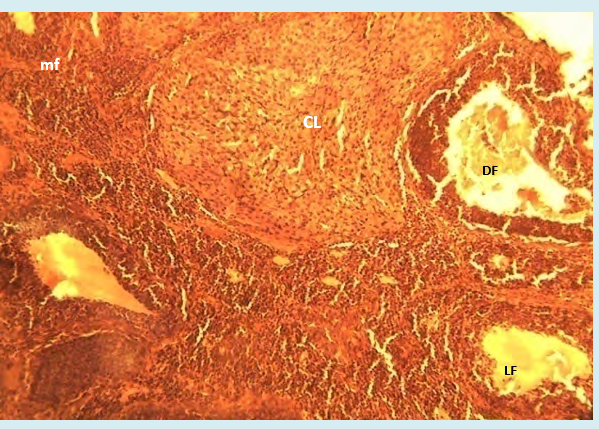

$200 \mathrm{mg} / \mathrm{kg}$ bw of Boerhavia diffusa treated (Group III)

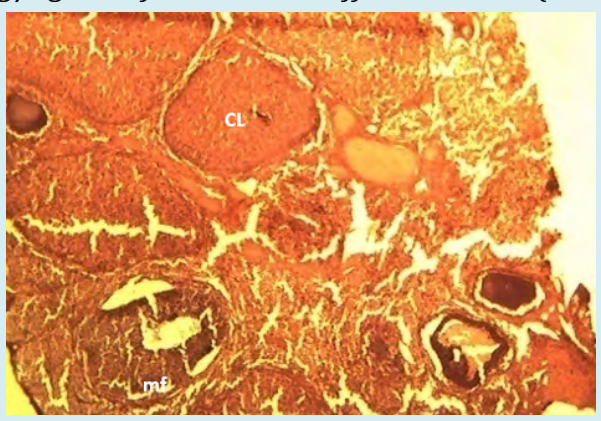

$400 \mathrm{mg} / \mathrm{kg}$ bw of Boerhavia diffusa treated (Group V)

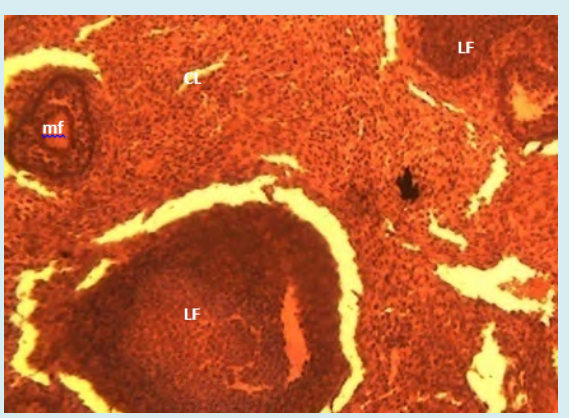

Cypermethrin Reproductive dysfunction-induced (II)

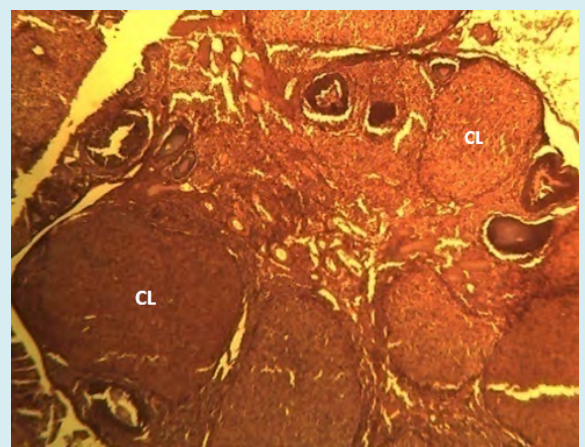

$300 \mathrm{mg} / \mathrm{kg}$ bw of Boerhavia diffusa treated (Group IV)

Figure 1: Histo-Micrograph of the Ovary for Boerhavia diffusa Extract Treated Rats.

Key: CL: corpus luteum, df: degenerative follicles, MF: medium size (secondary) follicles, LF: Large (matured) follicular cells. Hematoxylin and Eosin $x 400$ 


\section{Discussion}

One of the most frequently used group of insecticides are the synthetic pyrethroids. Recently, their continuous use have reportedly caused increase in the levels of chlorines, phosphates and carbamates from organic sources, possibly rapidly degrading, and affecting mammalian toxicity by its action mechanism. Cypermethrin, being a common pyrethroid is useful agriculture and forestry, also in public and animal health fields. Although Cypermethrin has been considered to be nontoxic to mammals, reports have however shown its adverse effects on the neuro-endocrine, renal, hepatic and reproductive systems [16-19] of laboratory animals; with reproductive toxicity reports posing huge concerns due to susceptibility to chronic exposures. Hence, current study was embarked upon to investigate the reproductive toxicity associated with cypermethrin; and the ameliorative potentials of varying Boerhavia diffusa extract doses in female Wistar rats. Twenty five (25) wistar rats (between 150-200 g) were first procured and acclimatized (two weeks) for this study; following which they were grouped into 5 of $n=5$ per group. Group I animals were fed standard chow and water at free will (normal control), while inducing reproductive dysfunction in group II rats by oral administration of 3.83 $\mathrm{mg} / \mathrm{kg}$ bw of cypermethrin for 14 days (negative control). Groups III, IV and V then received (orally) $200 \mathrm{mg} / \mathrm{kg}$ bw, $300 \mathrm{mg} / \mathrm{kg}$ bw and $400 \mathrm{mg} / \mathrm{kg}$ bw of Boerhavia diffusa extract (ethanolic) for five weeks respectively; haven also induced reproductive dysfunction with $3.83 \mathrm{mg} / \mathrm{kg}$ bw of cypermethrin.

In this study, Body weight being a valuable indicator of reproductive health was assessed (weekly) across groups (table I). from our result, there was a reduction in body weight of negative control group (II) compared to group I. whereas, administration of varying doses of ethanolic Boerhavia diffusa leaf extract caused a significant $(\mathrm{p}<0.05)$ weekly increase in body weights of all experimental animals compared with control. This increase may portend huge recovery across groups following test administration; and may alter serum sex hormone levels as well (though un-assayed for) to implicate test extract as a possible potent repro-degenerative ameliorator. This finding is in concordance previous other reports, where cypermethrin treatment was associated with body weight recovery and serum Testosterone, Luteinizing and Follicle Stimulating Hormone levels [20-23].

Also From table II report of current study, the effect(s) of feeding female wistar rats with varying doses of ethanolic Boerhavia diffusa extract was assayed for selected hematological parameters. From the table, there was a noticeable significant reduction in all assayed hematological parameters for negative control group (II) but for TWBCC which was insignificant compared to control (group I). However, administration of varying doses of ethanolic Boerhavia diffusa leaf extract caused a significant improvement in all variables as compared to control; even though these increases were insignificant across groups for TWBCC as compared with control. Values obtained from the TPC, TWBCC and TRBCC show that B. diffusa ethanolic extract had the most promising effect with increasing doses/ regimen; with remarkable improvements in animals' physical and behavioural properties as observed.

Again, a clear look at table III reveals a summary of the Histo-Pathological differences observed in the ovaries of Boerhavia diffusa extract treatments to rats at various doses. Here, only moderate number of secondary follicles were noticed in all treatments except group IV; were as, cystic follicles were noticed in Cypermethrin fed, reproductive dysfunctional rats of group II (negative control) as compared to others.

Histologically, this observation showed no noticeable change in the ovaries of treatment groups as against the control and those induced with reproductive dysfunction. However, degenerative follicles of varying sizes were noticed with Hematoxylin and Eosin at a X 400 microscope resolution.

\section{Conclusion}

In this study, the ameliorative potentials of ethanolic leaf extract of Boerhavia diffusa was investigated on reproductive and selected hematological variables in wistar rats. From our results, a statistically significant reduction was observed in body weight of $3.83 \mathrm{mg} / \mathrm{kg}$ bw of cypermethrin fed rats (reproductive dysfunctional group) as compared to group I. whereas, administration of varying doses of ethanolic Boerhavia diffusa leaf extract caused a significant $(\mathrm{p}<$ 0.05 ) increase in body weights of all experimental animals compared with control group. Also, moderate number of secondary follicles were noticed in all treatments except group IV; were as, cystic follicles were noticed in Cypermethrin fed, reproductive dysfunctional rats. Albeit, histological observations showed no noticeable change in the ovaries of treatment groups as against the control.

\section{References}

1. Brahamvarchas (2006) Ayurved ka Pran Vanoshadi Vigyan. $6^{\text {th }}$ (Edn.), Yug Nirman Yojna Gayatri Tapobhumi, Mathura, pp: 100-101.

2. John D (1984) One Hundred Useful Raw Drugs of the Kani Tribes of Trivandrum Forest Division, Kerala, India. Int J Crude Drug Res 22(1): 17-39.

3. Basak SK (1997) Medicinal plants of Bankura (W.B.) and their uses. J Natl Bot Soc 51: 61-68. 
4. Tripathi YC, Prabhu VV, Pal RS, Mishra RN (1996) Medicinal plants of Rajasthan in Indian system of medicine. Anc Sci Life 15(3): 190-212.

5. Merck Manual (2012) Hematologic reference ranges. Mareck Veterinary Manual.

6. Sebastian MK, Bhandari MM (1988) Medicinal plant lore of Udaipur district, Rajasthan. Bull Med Ethnobot Res 5: 3-4.

7. Togun VA, Oseni BSA, Ogundipe JA, Arewa TR, Hammed AA, et al. (2007) Effects of chronic lead administration on the haematological parameters of rabbits - a preliminary.

8. Kapur SK (2013) J Econ Taxonomic Bot 17: 395-408.

9. Kokate CK, Purohit AP, Gokhale SB (2004) Alkaloidal drugs. Pharmacognosy. $13^{\text {th }}$ (Edn.). Pune: Nirali Prakasan, pp: 593-597.

10. Hansen K, Nyman U, Smitt UW, Adsersen A, Gudiksen $\mathrm{L}$, et al. (2015) In vitro screening of traditional medicines for anti-hypertensive effect based on inhibition of the angiotensin converting enzyme (ACE). J Ethanopharmacol 48(1): 43-51.

11. Pari L, Sathees MA. (2014) Antidiabetic activity of Boerhaavia diffusa L.: effect on hepatic key enzymes in experimental diabetes. J Ethanopharmacol 91(1): 109113.

12. Borrelli F, Ascione V, Capasso R, Izzo AA, Fattorusso E (2011) Potent antioxidant and genoprotective effects of Boeravinone $\mathrm{G}$, a retinoid isolated from Boerhaavia diffusia 6(5).

13. Hilou A, Nacoulma OG, Guiguemde TR (2016) In vivo antimalarial activities of extracts from Amaranthus spinosus L. and Boerhaavia erecta L. in mice. J Ethanopharmacol 103(2): 236-240.

14. William J, Hrushesky MD (1978) Subcutaneous HeparinInduced Thrombocytopenia. Arch Intern Med 138(10):
1489-1491.

15. Boerhavia diffusa was originally described and published in Species Plantarum 1: 3. 1753. Boerhavia diffusa. Germplasm Resources Information Network (GRIN) Agricultural Research Service (ARS), United States Department of Agriculture (USDA).

16. Debjit B, Sampath KP, Shweta S; Shravan P, Amit S; et al. (2012) Traditional Indian Herbs: Punarnava and Its Medicinal Importance. Research Journal of Pharmacognosy and Phytochemistry 1(1): 52-57.

17. Sherwin Carlquist (2008) Dispersal to Islands. Plant Discorveries: Sherwin Carlquist.

18. Hu JX, Li YF, Li J, Pan C, He Z, et al. (2013) Toxic effects of cypermethrin on the male reproductive system: With emphasis on the androgen receptor. J Appl Toxicol 33(7): 576-585.

19. Sushma N, Devasena $T$ (2010) Aqueous extract of Trigonella foenum graecum (fenugreek) prevents cypermethrin-induced hepatotoxicity and nephrotoxicity. Hum Exp Toxicol 29(4): 311-319.

20. Wang XZ, Liu SS, Sun Y, Wu JY, Zhou YL, et al. (2009) Beta-cypermethrin impairs reproductive function in male mice by inducing oxidative stress. Theriogenology 72(5): 599-611.

21. Wang H, Wang Q, Zhao XF, Liu P, Meng XH, et al. (2010) Cypermethrin exposure during puberty disrupts testosterone synthesis via downregulating StAR in mouse testes. Arch Toxicol 84(1): 53-61.

22. Joshi SC, Bansal B, Jasuja ND (2011) Evaluation of reproductive and developmental toxicity of cypermethrin in male male albino rats. Toxicol Environ Chem 93(3): 593-602.

23. Liu L, Hu JX, Wang H, Chen BJ, He Z, et al. (2010) Effects of beta-cypermethrin on male rat reproductive system. Environ Toxicol Pharmacol 30(3): 251-256. 